\title{
The Profile and Severity of Causal Factors in Symptomatic Epilepsies
}

\section{Semptomatik Epilepsilerde Altta Yatan Nedenler ve Ağırlık Dereceleri}

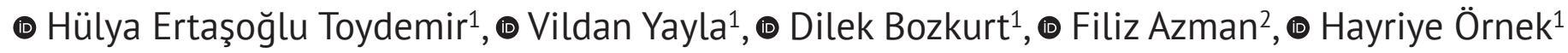 \\ ${ }^{1}$ University of Health Sciences Turkey, Bakırköy Dr. Sadi Konuk Training and Research Hospital, Clinic of Neurology, Istanbul, Turkey \\ ${ }^{2}$ Kayseri City Hospital, Clinic of Neurology, Kayseri, Turkey
}

Background: The purpose of this study was to identify the profile of causal factors, to estimate severity of causal factors, and to evaluate the relationship between them and the clinical features of our patients with symptomatic epilepsy.

Materials and Methods: We retrospectively analyzed demographic, clinical, electroencephalographic and radiological findings and causal factors of 128 patients. Patients were grouped in three according to the number of causal factors which were hypothesized to represent the severity. The relationships between the severity of causal factors and clinical, electroencephalographic or radiological findings were evaluated.

Results: The most frequent causal factors were head trauma, prenatal/perinatal/postnatal problems, mesial temporal sclerosis and central nervous system infections. Group 1 consisted of 73 patients (57\%) having one causal factor. In group 2, 32\% had two causal factors and in group 3,11\% had more than two causal factors. There were no significant differences between the severity of causal factors and age, sex, delivery problems, mental status, radiological or electroencephalographic findings. There existed a significant difference only in terms of encephalomalacia $(p=0.008)$ Encephalomalacia was more frequently detected in patients having more than two causal factors.

Conclusion: A wide variety of one or more causal factors may be detected in patients with symptomatic epilepsies. The severity of the causal factors may not be easily evaluated. The number of causal factors may represent the severity of the insult and may have influences on the electro-clinical or radiological findings. Future studies are required for the prediction of the severity of the underlying causes and the type of pathological process.

Keywords: Symptomatic epilepsy, causes of epilepsy, risk factors

Amaç: Çalışmamızda semptomatik epilepsisi olan hastalarda altta yatan nedenleri tanımlamak, bu nedenlerin ağırlık derecelerini tayin etmek ve hastaların klinik özellikleri ve bu nedenler arasındaki ilişkiyi değerlendirmek amaçlandı.

Gereç ve Yöntemler: Yüz yirmi sekiz hastanın demografik, klinik, elektroensefalografik, radyolojik bulguları ve epilepsi nedenleri retrospektif olarak analiz edildi. Hastalar, epilepsinin altta yatan nedenlerinin ağırlık derecesini yansıttığı düşünülerek bu nedenlerin sayısına göre üç gruba ayrıldı. Epilepsi nedenlerinin ağırlık dereceleri ile hastaların klinik, elektroensefalografik ve radyolojik bulguları arasındaki ilişki değerlendirildi.

Bulgular: En sık epilepsi nedenleri kafa travması, prenatal/perinatal/postnatal problemler, mezial temporal skleroz ve merkezi sinir sistemi enfeksiyonlarıydı. Tek neden saptanan 73 hasta (\%57) grup 1'i oluştururken, iki neden saptanan \%32 hasta grup 2'de, ikiden fazla neden saptanan \%11 hasta grup 3’te bulunuyordu. Epilepsi nedenlerinin ağırlık dereceleri ile yaş, cinsiyet, doğum problemleri, mental durum ve elektroensefalografik bulgular arasında anlamlı ilişki saptanmadı. Sadece ensefalomalazi ile epilepsi nedeninin ağırlık derecesi arasında istatistiksel anlamlı ilişki mevcuttu $(p=0,008)$. Ensefalomalazi, ikiden fazla neden saptanan hastalar arasında daha sıktı.

Sonuç: Semptomatik epilepsisi olan hastalarda iki veya daha çok neden, çok geniş çeşitlilikte saptanabilmektedir. Nedenlerin ağırlık dereceleri kolay saptanamayabilir. Altta yatan nedenlerin sayısının, hasarın ağırlık derecesini yansıtabileceği ve elektro-klinik, radyolojik bulgular üzerine etkisi olabileceği düşünülmüştür. Gelecekte, epilepsi nedenlerinin ağırlık derecesini ve patolojik sürecin tipini öngörebilmeye yönelik başka çalışmalara ihtiyaç vardır.

Anahtar Kelimeler: Semptomatik epilepsi, epilepsi nedenleri, risk faktörleri

Address for Correspondence: Hülya Ertaşoğlu Toydemir, University of Health Sciences Turkey, Bakırköy Dr. Sadi Konuk Training and Research Hospital, Clinic of Neurology, istanbul, Turkey

Phone: +90 5053743369 E-mail: hulyatoydemir@hotmail.com ORCID ID: orcid.org/0000-0002-2024-1181

Received: 03.04.2021 Accepted: 21.09.2021 


\section{Introduction}

Symptomatic epilepsy (SE) is the epilepsy in which convulsions are due to a central nervous system (CNS) insult that may be metabolic, toxic, structural, infectious, or inflammatory (1). SE has been described as "an epilepsy predominantly due to a gross neuroanatomical or neuropathological abnormality or a relevant systemic disease, which can be acquired or genetic in origin" (2). Underlying etiologies, investigations and treatment of symptomatic seizures are different from that of unprovoked seizures (3).

Symptomatic epilepsies are not always acquired. Genetic or developmental causation may be detected for some of the symptomatic epilepsies, such as progressive myoclonic epilepsies, neurocutaneous syndromes, disorders of chromosome structure and developmental anomalies of cerebral structure. Symptomatic epilepsies of acquired causation consist of hippocampal sclerosis, perinatal and infantile causes, cerebral trauma, tumor, infection, cerebrovascular disorders, cerebral immunologic disorders and degenerative conditions (2). In the majority of cases, epilepsy is multifactorial and has contributions from genetic, acquired and precipitating causes (4). The concepts of proximate and remote causes underlying symptomatic epilepsies were evaluated in previous studies $(2,5)$. A proximate cause was considered to be an actual cellular disturbance at the epileptic focus and remote causes were defined to be those which triggered this disturbance (5).

Causal factors, remote or proximate, are extremely important in the concept of symptomatic epilepsy. Sometimes there may be difficulties in defining the causal factors or there may be more than one causal factor underlying symptomatic epilepsies. Moreover, recognition of the severity of insult required to precipitate seizures and the determination of a temporal relationship might have influences on the understanding of the concept of SE. The severity of the insult might be understood with four conceptual models: 1acute disease model in which multiple insults are needed to provoke a seizure; 2-chronic disease model in which seizures happen after a single insult in the context of a chronic disease; 3- unique insult model in which seizures occur due to high-magnitude insult; and 4- genetic predisposition in which seizures happen after an insult of low intensity $(5,6)$. The purpose of this study was (i) to identify the profile of causal factors, (ii) to estimate severity of causal factors, and (iii) to evaluate the relationship between the severity of causal factors and the clinical features of our patients with symptomatic epilepsy.

\section{Material and Methods}

A retrospective analysis was performed to 128 patients with SE attending to our epilepsy outpatient clinic in a 3 -year-period. The inclusion criteria were the presence and the documentation of a CNS insult. Patients with acute or chronic setting were both included in the study. Patients with inadequate data or the patients whose causal factor could not be defined were excluded. Besides demographic findings of the patients, causal factors, radiologic and electro-clinical features were recorded.

Epileptic seizures were classified according to the ILAE classification as simple partial seizures, complex partial seizures, absence, myoclonic seizures, generalized tonic clonic seizures, secondary generalized tonic clonic seizures and status epilepticus (7).

Cranial magnetic resonance imaging (MRI) according to epilepsy protocol was undertaken to investigate the presence of structural brain abnormality. All of our patients had at least one cranial MRI during their follow-up.

Electroencephalographic (EEG) findings were grouped in five as focal epileptogenic focus, generalized epileptiform activity, focal slowing in fronto-temporal region, non-specific paroxysmal activity and generalized slowing.

We categorized head trauma as minor (<30 min amnesia and no skull fracture) or major head trauma ( $>30$ min amnesia and/or skull fracture and/or intracranial traumatic lesions).

Prenatal/perinatal/postnatal problems were not evaluated separately. Problems during pregnancy such as infections and trauma, delivery problems such as difficult and prolonged labor, complicated labor, problems after birth such as prolonged neonatal jaundice, kernicterus were termed as prenatal/perinatal/postnatal problems. Information about prenatal/perinatal/postnatal problems was obtained from patients, parents, care givers, previous medical documents or the medical records of the hospital.

A wide variety of causal factors in our study population and the presence of more than one causal factor in the same patient allowed us to make a hypothesis that the number of causal factors might represent the severity of the insult and might have influences on the electro-clinical or radiological findings of the patients. For this reason, causal factors underlying the seizures were listed and then patients were categorized in three groups according to the number of causal factors. Patients presenting with only one causal factor belonged to group 1, patients with two causal factors were in group 2 and the ones with more than two causal factors constituted group 3. These groups were defined to represent the level of severity of causal factors. The relationship between the severity of causal factors and the clinical features of our patients with SE were evaluated. 


\section{Statistical Analysis}

We performed statistical analysis by NCSS (Number Cruncher Statistical System) 2007 software program (NCSS, LLC Kaysville, Utah, USA). Besides descriptive statistical methods (mean, standard deviation, median, frequency and ratio), data were analyzed by using the One-Way ANOVA test for qualitative variables with normal distribution between the groups. The Pearson's chi-square test $\left(\chi^{2}\right)$ and Fisher Freeman Halton test were used for the analysis of quantitative variables. Data were evaluated within a $95 \%$ confidence interval and a $\mathrm{p}$-value $<0.05$ was considered significant.

\section{Results}

Among the 128 patients included in this study, 71 patients (55.5\%) were male and 57 patients (44.5\%) were female. The mean age of the patients was $31.91 \pm 13.76$ (1281) years. Ages at seizure onset were between the first year of life and 80 years (mean: 18.17 \pm 13.91 years). The mean latent period between the insult and the age at seizure onset was $11.81 \pm 9.85$ years (min-max: 6 months- 46 years). Causal factors underlying symptomatic seizures of our patients are listed in Table 1. The most frequent causal factors were head trauma, prenatal/perinatal/postnatal problems, mesial temporal sclerosis (MTS) and CNS infections.

Patients were grouped in three according to the number of causal factors. Group 1 consisted of 73 patients (57.0\%) with one causal factor, group 2 included 41 patients (32.0\%) with two causal factors and in group 3,14 patients (11.0\%) had more than two causal factors. Neurological examination was unremarkable in 72 (56.3\%) patients, 15 (11.7\%) patients had motor-mental retardation, 13 (10.2\%) had hemiparesis, 12 (9.4\%) had mental retardation, and the rest had other neurological deficits including tremor, vision loss, dysmetria, ataxia, dysarthria and hemihypoesthesia.

Seizure types in our study population consisted of 7 subtypes: generalized tonic clonic (52.3\%), complex partial (49.2\%), simple partial (23.4\%), secondary generalized (6.6\%), absence (2.3\%), myoclonic seizures (2.3\%) and status epilepticus (7.0\%).

Neuroimaging modalities revealed pathological findings in 101 patients (78.9\%). Pathological findings were encephalomalacia (32.8\%), MTS (12.5\%), periventricular ischemic-gliotic lesions (8.6\%), cortical dysplasia (6.3\%), periventricular leukomalacia (5.5\%), global atrophy (4.7\%), hemiatrophy (3.9\%), infarction (2.3\%), tumor (2.3\%), diffuse white matter lesions (2.3\%), arachnoid cyst (2.3\%), and aneurysms (0.8\%).

Pathological EEG findings, which were detected in $72.7 \%$ of the patients, were grouped in five: focal epileptogenic focus (58.1\%), focal slowing in fronto-temporal region (39.8\%), generalized slowing (20.4\%), generalized epileptiform activity (15.1\%) and non-specific paroxysmal activity (10.8\%).

Analysis revealed no significant differences between the severity of causal factors and sex or age $(p=0.320$ and $p=0.299$ ).

There were no significant differences between the severity of causal factors and problems of delivery or mental status ( $p=0.699$ and $p=0.453$ ).

We did not find any significant differences between the severity of causal factors and radiological findings globally $(p=0.599)$. There existed a significant difference only in terms of encephalomalacia $(p=0.008)$. Encephalomalacia was more frequently detected in patients who had more than two causal factors underlying their symptomatic seizures (group 3) (Table 2).

Analysis of the relationship between the severity of causal factors and pathological EEG findings showed no significant difference between the groups ( $p=0.409$ ). In addition, there was no significant difference between the subgroups of EEG pathological findings (Table 3).

\begin{tabular}{|l|l|l|}
\hline \multicolumn{3}{|l}{ Table 1. Causal factors of symptomatic seizures in our patients } \\
\hline & $\mathbf{n}$ & $\%$ \\
\hline Trauma (head) & 46 & 35.9 \\
\hline Minor & 21 & 51.2 \\
\hline Major & 20 & 48.8 \\
\hline Prenatal, perinatal postnatal problems & 32 & 25.0 \\
\hline Mesial temporal sclerosis & 30 & 23.4 \\
\hline Right-sided & 10 & 33.3 \\
\hline Left-sided & 15 & 50.0 \\
\hline Bilateral & 5 & 16.7 \\
\hline Central nervous system infections & 19 & 14.8 \\
\hline Brain operations & 12 & 9.4 \\
\hline Congenital malformations & 12 & 9.4 \\
\hline Cerebrovascular diseases & 7 & 5.5 \\
\hline Ischemic & 4 & 57.1 \\
\hline Hemorrhagic & 3 & 42.9 \\
\hline Arteriovenous malformations/aneurysms & 6 & 4.7 \\
\hline Brain tumor & 5 & 3.9 \\
\hline Other causal factors & 11 & 8.6 \\
\hline Cavernous angioma & 3 & 33.3 \\
\hline Tuberous sclerosis & 2 & 22.2 \\
\hline Neuroepithelial cyst & 1 & 11.1 \\
\hline Coroid fissure cyst & 1 & 11.1 \\
\hline Epidermoid cyst & 1 & 11.1 \\
\hline DNET & & 11.1 \\
\hline DNET: Dysembryoblastic neuroepithelial tumor & \\
\hline & 3 & \\
\hline
\end{tabular}


Table 2. The relationship of the severity of causal factors with radiological findings

\begin{tabular}{|c|c|c|c|c|c|}
\hline & & \multicolumn{3}{|c|}{ Severity of causal factors } & \multirow[b]{2}{*}{$\mathbf{p}$} \\
\hline & & $\begin{array}{l}\text { Group } 1 \\
(n=55)\end{array}$ & $\begin{array}{l}\text { Group } 2 \\
(n=34)\end{array}$ & $\begin{array}{l}\text { Group } 3 \\
(n=12)\end{array}$ & \\
\hline \multirow{2}{*}{ Encephalomalacia } & No & $39(70.9)$ & $17(50.0)$ & $3(25.0)$ & \multirow{2}{*}{$0.008^{* *}$} \\
\hline & Yes & $16(29.1)$ & $17(50.0)$ & $9(75.0)$ & \\
\hline \multirow{2}{*}{ Periventricular ischemia } & No & $48(87.3)$ & $30(88.2)$ & $12(100.0)$ & \multirow{2}{*}{0.599} \\
\hline & Yes & $7(12.7)$ & $4(11.8)$ & 0 & \\
\hline \multirow{2}{*}{ Tumor } & No & $54(98.2)$ & 33 (97.1) & $11(91.7)$ & \multirow{2}{*}{0.356} \\
\hline & Yes & $1(1.8)$ & $1(2.9)$ & $1(8.3)$ & \\
\hline \multirow{2}{*}{ Aneurysms } & No & $55(100.0)$ & $34(100.0)$ & $11(91.7)$ & \multirow{2}{*}{0.122} \\
\hline & Yes & 0 & 0 & $1(8.3)$ & \\
\hline \multirow{2}{*}{ Diffuse white matter lesions } & No & $54(98.2)$ & $32(94.1)$ & $12(100.0)$ & \multirow{2}{*}{0.701} \\
\hline & Yes & $1(1.8)$ & $2(5.9)$ & 0 & \\
\hline \multirow{2}{*}{ Periventricular leukomalacia } & No & $50(90.9)$ & $32(94.1)$ & $12(100.0)$ & \multirow{2}{*}{0.746} \\
\hline & Yes & $5(9.1)$ & $2(5.9)$ & 0 & \\
\hline \multirow{2}{*}{ Hemiatrophy } & No & $52(94.5)$ & $33(97.1)$ & $11(91.7)$ & \multirow{2}{*}{0.671} \\
\hline & Yes & $3(5.5)$ & $1(2.9)$ & $1(8.3)$ & \\
\hline \multirow{2}{*}{ Cortical dysplasia } & No & $52(94.5)$ & $31(91.2)$ & $10(83.3)$ & \multirow{2}{*}{0.312} \\
\hline & Yes & $3(5.5)$ & $3(8.8)$ & $2(16.7)$ & \\
\hline \multirow{2}{*}{ Global atrophy } & No & $52(94.5)$ & $31(91.2)$ & $12(100.0)$ & \multirow{2}{*}{0.709} \\
\hline & Yes & $3(5.5)$ & $3(8.8)$ & 0 & \\
\hline \multirow{2}{*}{ Infarction } & No & $52(94.5)$ & $34(100.0)$ & $12(100.0)$ & \multirow{2}{*}{0.515} \\
\hline & Yes & $3(5.5)$ & 0 & 0 & \\
\hline \multirow{2}{*}{ Mesial temporal sclerosis } & No & $48(87.3)$ & $25(73.5)$ & $12(100.0)$ & \multirow{2}{*}{0.077} \\
\hline & Yes & $7(12.7)$ & $9(26.5)$ & 0 & \\
\hline
\end{tabular}

\section{Discussion}

Our study demonstrates that a wide variety of causal factors may be detected in patients with symptomatic epilepsies. The most frequent causal factors are listed as head trauma, prenatal/perinatal/postnatal problems, MTS and CNS infections. Although clinical and laboratory findings vary according to the underlying causal factors in symptomatic epilepsies, more than one causal factor may be found in the same patient. It may not be easy to evaluate the severity or intensity of the causal factor needed to provoke a seizure. We aimed to find out whether the number of causal factors has an influence on the electro-clinical or radiological findings of the patients.

Epilepsy was stated to develop after an acute brain insult, such as traumatic brain injury (TBI), ischemic stroke, intracerebral hemorrhage, infection, and prolonged acute symptomatic seizures such as complex febrile seizures or status epilepticus in at least $40 \%$ of cases (8). Traumatic brain injury, stroke, drug withdrawal and metabolic insults were reported to be the commonest causes among adults in developed countries by Hauser and Beghi (9). The major causes of acute symptomatic seizure were listed as traumatic brain injury, stroke, drug withdrawal and CNS infections by Annegers et al. (10). CNS infections and stroke were found to be the prominent causes of acute symptomatic seizures in Nwani et al.(11). Causes underlying symptomatic seizures may vary according to the developmental status of the countries. In our series, the most common causal factor was head trauma as in line with previous studies. Powell categorized head injury as mild ( $<30 \mathrm{~min}$ amnesia and no skull fracture), moderate ( $>30 \mathrm{~min}$ amnesia and/or skull fracture) or severe (amnesia $>24 \mathrm{~h}$, cerebral contusion or intracranial hematoma) in a previous report (3). We categorized head trauma as minor ( $<30$ min amnesia and no skull fracture) or major head trauma (>30 min amnesia and/or skull fracture and/or intracranial traumatic lesions).

Prenatal/perinatal/postnatal problems were the second most common causes of symptomatic seizures in our study 
Table 3. The relationship of the severity of causal factors with pathological electroencepholographic findings

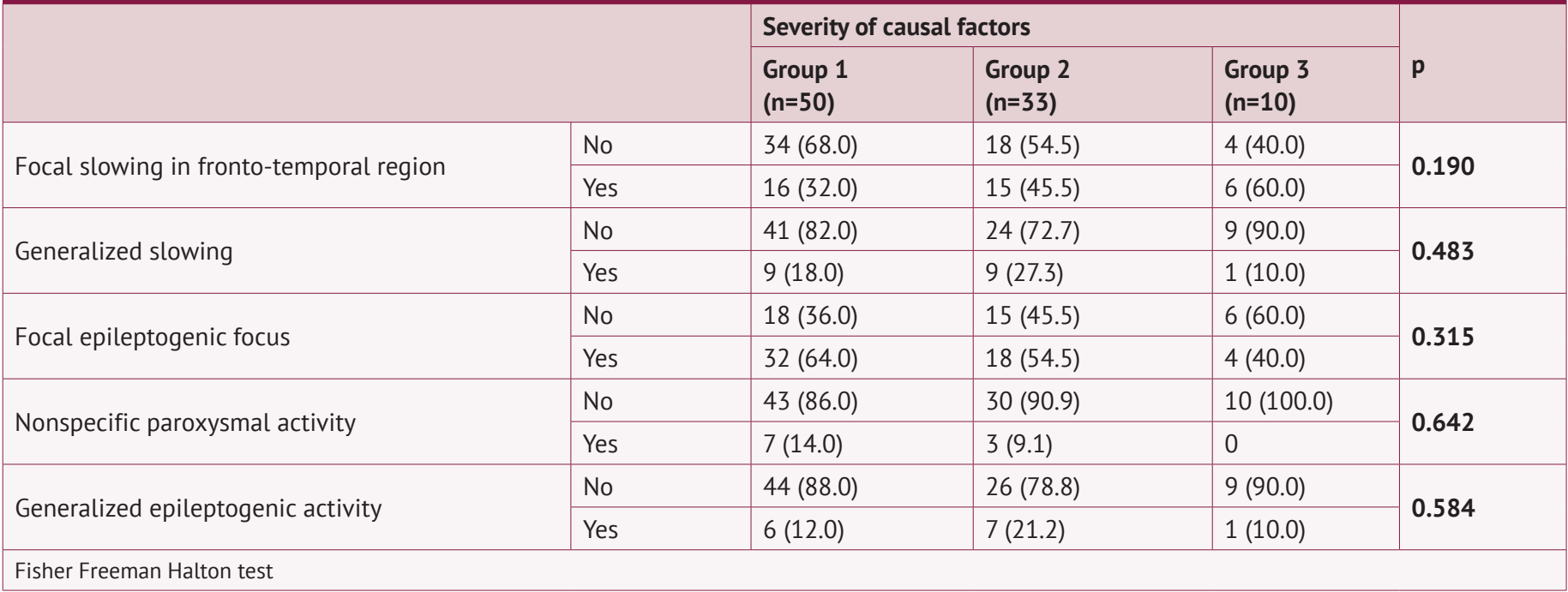

population. We obtained this medical past information from patients, parents, care givers, previous medical documents or the medical records of the hospital. We noticed that our patients or their primary care givers might have difficulties in reporting causal factors related to birth history definitely. Prematurity, problems related to delivery, metabolic or systemic problems in the postnatal period, febrile seizures and many other conditions might have been all termed as prenatal/perinatal/postnatal problems. This might explain the high frequency of these pathological conditions in our study population.

The most common radiological finding was encephalomalacia followed by MTS. In the literature, encephalomalacia is described as loss of brain tissue after cerebral infarction, cerebral ischemia, infection, craniocerebral trauma, or other injury. The term "encephalomalacia" is usually used for gross radiological abnormalities and many pathological lesions may be named as encephalomalacia. For this reason, our finding was not surprising because our radiologists also reported sequela lesions related to TBI, brain operations, cerebrovascular diseases as encephalomalacia.

Focal epileptogenic focus and focal slowing were the most common EEG findings in our patients. This was consistent with the profile of causal factors which were expected to produce a focal brain injury like head trauma, MTS, brain operations, congenital malformations, cerebrovascular diseases, tumors, aneurysms or other intracranial lesions.

Our analysis did not reveal any significant difference between the severity of causal factors and radiological or EEG findings. There existed a significant difference only in terms of encephalomalacia. Encephalomalacia was more frequently detected in patients who had more than two causal factors underlying their symptomatic seizures. Seizures in the setting of more than two causes were detected in 14 (10.9\%) of our patients. It may be argued that encephalomalacia might be caused by the first or the second insults and the third (the most proximate) insult might have highest potential to produce seizures but it might not be easy to determine the exact intensity of each causal factor. This was why we grouped our patients according to the number of causal factors to predict their severity. In addition, the process of epileptogenesis may take a time to develop and physiological basis of epileptogenesis is not well known $(2,12,13,14,15,16,17)$. Löscher concluded that no latent period was needed to acquire epilepsy and stated that currently it was not known when the brain first became "epileptic" (18).

\section{Study Limitations}

There are limitations of this study. First limitation is the small sample size. Secondly, we did not investigate the distribution of causal factors according to different age groups. We rather focused on the identification of the profile of causal factors and the estimation of their severity. Further studies with larger patient population and different age groups may strengthen the profile of symptomatic seizures and may contribute to the clinical management of patients with symptomatic epilepsies.

\section{Conclusion}

Acute symptomatic seizures should be differentiated from unprovoked seizures (13). Sometimes, causal factors may not be detected easily and this may lead to difficulties in the diagnosis and classification. Epilepsy in most cases has a multifactorial nature. Developments in EEG, histochemical and radiologic investigations might have big impact on the assignment of the causes of epilepsy. Invasive electrophysiological techniques and developed 
neuroimaging modalities might assist in detecting the underlying cause of epilepsy, which could not be found with standard investigations.

The severity or intensity of the causal factors may not be easily evaluated. The number of causal factors may represent the severity of the insult and may have influences on the electro-clinical or radiological findings of the patients. Both the severity and the number of causal factors have importance in the assessment of symptomatic epilepsies. Future trials on the prognosis of symptomatic epilepsies are required for the prediction of the severity of the underlying causes and the type of underlying pathological process.

\section{Ethics}

Ethics Committee Approval: The study were approved by the University of Health Sciences Turkey, Bakırköy Dr. Sadi Konuk Training and Research Hospital of Local Ethics Committee (protocol number: 2021/213).

Informed Consent: Retrospective study.

Peer-review: Internally peer-reviewed.

\section{Authorship Contributions}

Surgical and Medical Practices: H.E.T., V.Y., D.B., F.A., H.Ö., Concept: H.E.T., V.Y., D.B., F.A., H.Ö., Design: H.E.T., V.Y., D.B., F.A., H.Ö., Data Collection or Processing: H.E.T., V.Y., D.B., F.A., H.Ö., Analysis or Interpretation: H.E.T., V.Y., D.B., F.A., H.Ö., Literature Search: H.E.T., V.Y., D.B., F.A., H.Ö., Writing: H.E.T., V.Y., D.B., F.A., H.Ö.

Conflict of Interest: No conflict of interest was declared by the authors.

Financial Disclosure: The authors declared that this study received no financial support.

\section{References}

1. Beghi E, Carpio A, Forsgren L, Hesdorffer DC, Malmgren K, Sander JW, et al. Recommendation for a definition of acute symptomatic seizure. Epilepsia. 2010;51:671-675. [Crossref]
2. Shorvon S. The concept of symptomatic epilepsy and the complexities of assigning cause in epilepsy. Epilepsy Behav. 2014;32:1-8. [Crossref]

3. Powell R, McLauchlan DJ. Acute symptomatic seizures. Pract Neurol. 2012;12:154-165. [Crossref]

4. Lennox WG, Lennox M. Epilepsy and related disorders. Boston: Little Brown; 1960. [Crossref]

5. Beleza P. Acute symptomatic seizures. A clinically oriented review. Neurologist. 2012;18:109-119. [Crossref]

6. Delanty N, Vaughan CJ, French JA. Medical causes of seizures. Lancet. 1998;352:383-390. [Crossref]

7. Proposal for revised clinical and electroencephalographic classification of epileptic seizures. From the Commission on Classification and Terminology of the International League Against Epilepsy. Epilepsia. 1981;22:489-501. [Crossref]

8. Banerjee PN, Filippi D, Allen HW. The descriptive epidemiology of epilepsy-a review. Epilepsy Res. 2009;85:31-45. [Crossref]

9. Hauser WA, Beghi E. First seizure definitions and worldwide incidence and mortality. Epilepsia. 2008;49(Suppl 1):8-12. [Crossref]

10. Annegers JF, Hauser WA, Lee JRJ, Rocca WA. Incidence of acute symptomatic seizures in Rochester, Minnesota, 1935-1984. Epilepsia. 1995;36:327-333. [Crossref]

11. Nwani PO, Nwosu MC, Nwosu MN. Epidemiology of acute symptomatic seizures among adult medical admissions. Epilepsy Res Treat. 2016:1-5. [Crossref]

12. Löscher W. Basic aspects of epilepsy. Curr Opin Neurol Neurosurg. 1993;6:223-232. [Crossref]

13. Pitkänen A. New pharmacotherapy for epilepsy. IDrugs. 2004;7:471-477. [Crossref]

14. Dichter MA. Emerging concepts in the pathogenesis of epilepsy and epileptogenesis. Arch Neurol. 2009;66:443-447. [Crossref]

15. Dichter MA.Posttraumatic epilepsy:the challenge of translating discoveries in the laboratory to pathways to a cure. Epilepsia. 2009;50(Suppl 2):41-45. [Crossref]

16. Löscher W, Brandt C. Prevention or modification of epileptogenesis after brain insults: experimental approaches and translational research. Pharmacol Rev. 2010;62:668-700. [Crossref]

17. Pitkänen A, Lukasiuk K. Mechanisms of epileptogenesis and potential treatment targets. Lancet Neurol. 2011;10:173-186. [Crossref]

18. Löscher W, Hirsch $\sqcup$, Schmidt D. The enigma of the latent period in the development of symptomatic acquired epilepsy - traditional view versus new concepts. Epilepsy Behav. 2015;52:78-92. [Crossref] 